Ann. Biol. anim. Bioch. Biophys., I975, 15 (2), 243-253.

\title{
THE EFFECT OF OESTROGENS ALONE OR IN ASSOCIATION WITH PROGESTAGENS ON THE FORMATION AND REGRESSION OF THE CORPUS LUTEUM OF THE CYCLIC COW
}

\author{
Meredith LEMON \\ Station de Physiologie de la Reproduction. \\ Centre de Recherches de Tours, I. N. R. A., \\ Nousilly, 37380 Monnaie (France)
}

\section{SUMMARY}

Oestrogens show a variety of effects on the mammalian corpus luteum, depending on the stage of the oestrous cycle at which they are administered. This report discusses an investigation of the effect of a single injection of either $5 \mathrm{mg}$ oestradiol benzoate or $5 \mathrm{mg}$ oestradiol valerate, at all stages of the cycle in the cyclic cow. The concentration of plasma progesterone in daily peripheral blood samples, the apparition of oestrus and the occurrence of ovulation and pregnancy were the criteria used to evaluate the effects on the corpus luteum. A multiplicity of effects was the result : 1utcotrophic, or antiluteotrophic at the beginning of the cycle, luteolytic during most of the luteal phase, and anti-luteolytic at the end of the luteal phase.

The same criteria were used to evaluate the combination of treatment with a synthetic progestagen (norethandrolone or SC 2 roog) with a single injection of oestradiol valerate - treatments in current use for the synchronization of oestrus in cattle - with particular reference to treatments begun early in the oestrous cycle (Days 3 and 5), when an injection of this oestrogen alone has no luteolytic effect. It appears that SC 21009 in association with oestradiol valerate has a much greater inhibitory effect on the development of the corpus luteum than does the association of norethandrolone with oestradiol valerate.

\section{INTRODUCTION}

The administration of one of a number of synthetic progestagens, in association with a single injection of the oestrogen, oestradiol valerate, has become a classical treatment for the synchronization of oestrus in cattle. The most widely used proges- 
tagens in this laboratory are norethandrolone (Nilevar) in oral or injectable form, and SC 21009 (Norgestomet, Searle) in the form of subcutaneous implants (MACLEON, I974; ChUPIN et al., I974). They have been used in field trials under a multitude of conditions, and almost always, one is obliged to make a compromise between efficiency of synchronization and fertility. Both these progestagens, when used for a "short " duration of Io days, give better results from the point of view of synchronization when combined with oestradiol valerate, than when used alone. The first reports on the use of oestradiol valerate, and its "luteolytic effect ", were published by Wiltbank and co-workers (WILTBANK et al., I96I ; WILTBANK, Ig66; WILTBANK and KAssor, I968), but due to the difficulty of progesterone assay at that time, their criteria for evaluating the effects on the corpus luteum were imprecise. Their results showed, however, that the action of oestrogen depended on the stage of the oestrous cycle at which it was administered.

With the development of protein-binding, and radioimmuno-assays capable of measuring the steroids in peripheral circulation, it has been possible to take a closer look at what happens to the corpus luteum in terms of progesterone secretion, after various treatments with exogenous hormones. The experiments reported in this paper were designed to investigate the effect of a single injection of either oestradiol valerate or oestradiol benzoate at different stages of the oestrous cycle in the cow, and the effect of progestagen treatment with norethandrolone or $\mathrm{SC} 2$ roog alone, or in combination with oestradiol valerate injection. Throughout these experiments, the peripheral concentrations of plasma progesterone have been measured in order to follow the effects of treatment on the corpus luteum. The effects on the length of the oestrous cycle have also been noted, whether or not there was ovulation following oestrus, and in the oestrogen experiment, whether or not pregnancy followed artificial insemination at this oestrus.

\section{THE EFFECT OF OESTRADIOL BENZOATE}

\section{OR OESTRADIOL VALERATE INJECTION}

To compare the effects of the two oestrogens, oestradiol benzoate and oestradiol valerate, on the corpus luteum of the cyclic cow, the same dose as that used for synchronization of oestrus in association with progestagen treatment $(5 \mathrm{mg})$ was administered in a single intra-muscular injection at different stages throughout the oestrous cycle - days $3,6,9,12, I_{5}$ and 18 (Day o $=$ day of oestrus). The animals used were cyclic; 40 multiparous cows and 8 heifers, all of the Friesian, Pie noire breed. Half were injected with oestradiol benzoate and half with oestradiol valerate, with 4 animals per day of injection. Blood sampling from the jugular vein was carried out twice daily on the day before injection of the oestrogen, on the day of injection and for 3 days following, then once a day until oestrus occurred. Further samples were taken on Day 8 after oestrus, and on Day 23. A11 animals were inseminated at oestrus, and pregnancy was diagnosed (THIMONIER, I973) from the samples taken on Day 23. The concentration of progesterone in the plasma from all other samples was estimated by the competitive protein-binding technique of Thorburn, BASSE'T and Smith (I969). 
The plasma progesterone concentrations for each cow were plotted against the day of the cycle, and compared with a " mean, normal cycle " obtained by taking the mean progesterone concentrations during the 9 days before oestrus from 7 untreated, normal, cyclic cows. Three types of curve were obtained, depending on the stage of the cycle at which the oestrogen was injected, and the effects of treatment have been classified according to these progesterone curves. An anti-luteotrophic effect was considered as when the progesterone concentrations remained low $(<\mathrm{I}-2 \mathrm{ng} / \mathrm{ml})$ until the following oestrus, reflecting an inhibition of luteal development, an effect found in some, but not all cows injected early in the crcle, before the corpus luteum had formed. The reverse effect, a luteotrophic effect, was found in other cows injected at this time, and luteal development as seen by progesterone concentrations, exceeded that of a normal cycle, with luteal regression occurring later than normal. A luteolytic effect was defined as when luteal regression occurred earlier than in a normal cycle. It was also noted that often, when the luteolytic effect was seen, further corpus luteum development was suppressed if injection occurred before maximum secretory activity had been attained.
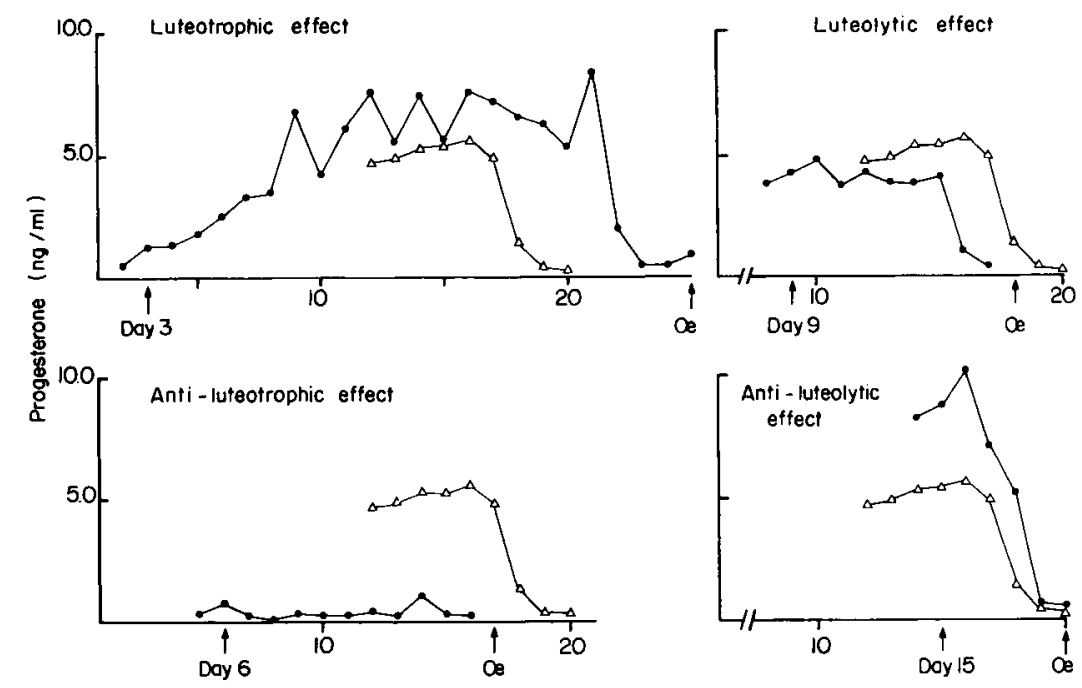

FIG. I. - Concentrations of plasma progesterone after injection of $5 \mathrm{mg}$ oestradiol benzont: or $5 \mathrm{ng}$ oestradiol valerate in the cyclic cow on different days of the oestrous cycle

$-\longrightarrow$ : treated cycle

: represents the second half of a "mean, normal cycle "obtained by calculating the mean progesterone concentrations from 7 crcles in untreated cyclic cows.

$\uparrow:$ injection of $5 \mathrm{mg}$ oestrogen

$\infty$ : day of oestrus

An analogous effect to the luteotrophic effect seen after injection at the beginning of the cycle, was observed as a result of injection late in the cycle, and was then defined as an anti-luteolytic effect. Figure I shows the evolution of progesterone concentrations after injection of one or other oestrogen at different stages of the oestrous cycle, illustrating the effects defined above in comparison with the "mean, normal curve". 
Table I represents a summary of the experiment, where the effects of oestrogen injection throughout the cycle are arranged according to this classification. The multiplicity of effects can be clearly seen, in particular, a period in the middle of the cycle which reflects a period of sensitivity of the corpus luteum to oestrogen injection. The luteolytic effect was shown in almost all cows injected with oestradiol benzoate on Days 9, I2 and $\mathbf{I}_{5}$. Luteal regression in these animals occurred two or three days earlier than normal, regression of a corpus luteum whose maximum secretory capacity was suppressed after injection. The same result was observed in animals injected on Day 9 with oestradiol valerate, and to a lesser extent on Days 6 , I2 and $I_{5}$. These results also suggest that oestradiol benzoate is a more efficient " luteolytic agent ", over a greater period of the cycle, than is oestradiol valerate.

TABIE I

Effect of injection of oestradiol benzoate or oestradiol valerate on the corpus luteum of the cyclic cow

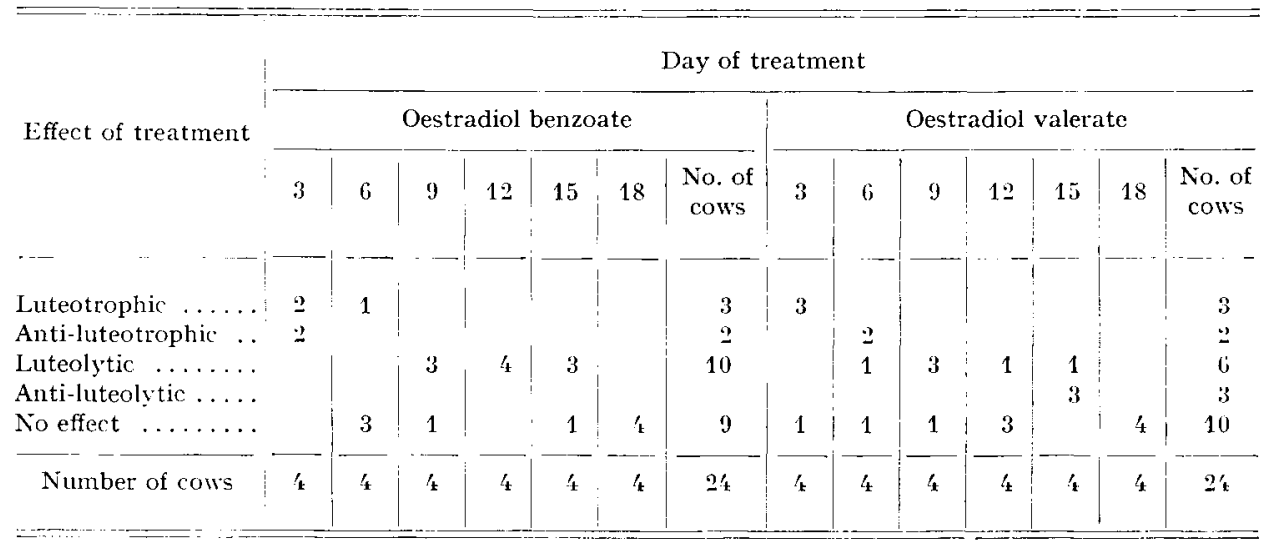

The consequence of these effects of oestrogen injection is that the life-span of the corpus luteum is altered, compared to the normal cycle, and thus, the time at which luteal regression is complete. A graphical representation of this phenomenon has been chosen (see fig. 2), given the individual differences in the response according to the day of injection of the oestrogen, and the limited number of observations which make statistical analysis impossible.

For each group of four cows per day of injection, each cow (identified by a number, I to 4) appears in the figure on the day of the cycle when the plasma progesterone concentration had decreased to less then $2 \mathrm{ng} / \mathrm{ml}$; it disappears from the figure the day after oestrus.

All the animals in each group do not necessarily appear, since the figure covers only the period from Day 16 to Day 20.

This method of representation takes into account the chronology of the luteal regression and the homogeneity of the responses, shown as cumulative, and the duration of the phase at low levels of progesterone (called classically, the follicular phase) shown by the time a given animal is represented in the figure. It can be seen 


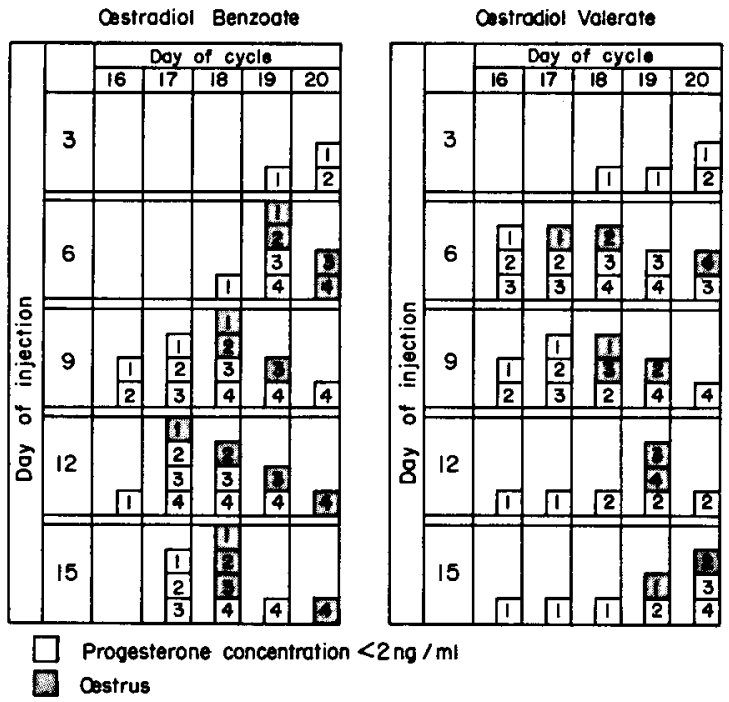

li $1 \mathrm{G} .2$. - The effect of oestrogen injection on subsequent luteal regression in the cyclic cout

Plasma progesterone concentration $<2 \mathrm{ng} / \mathrm{ml}$, the arbitrary value below which luteal regression is considered to be complete. Results are cumulative for a given day of injection show the progressing luteal regression on different days of the cycle and the effect of oestrogen injection on this paranieter in relation to the day of injection for the different treatment groups.
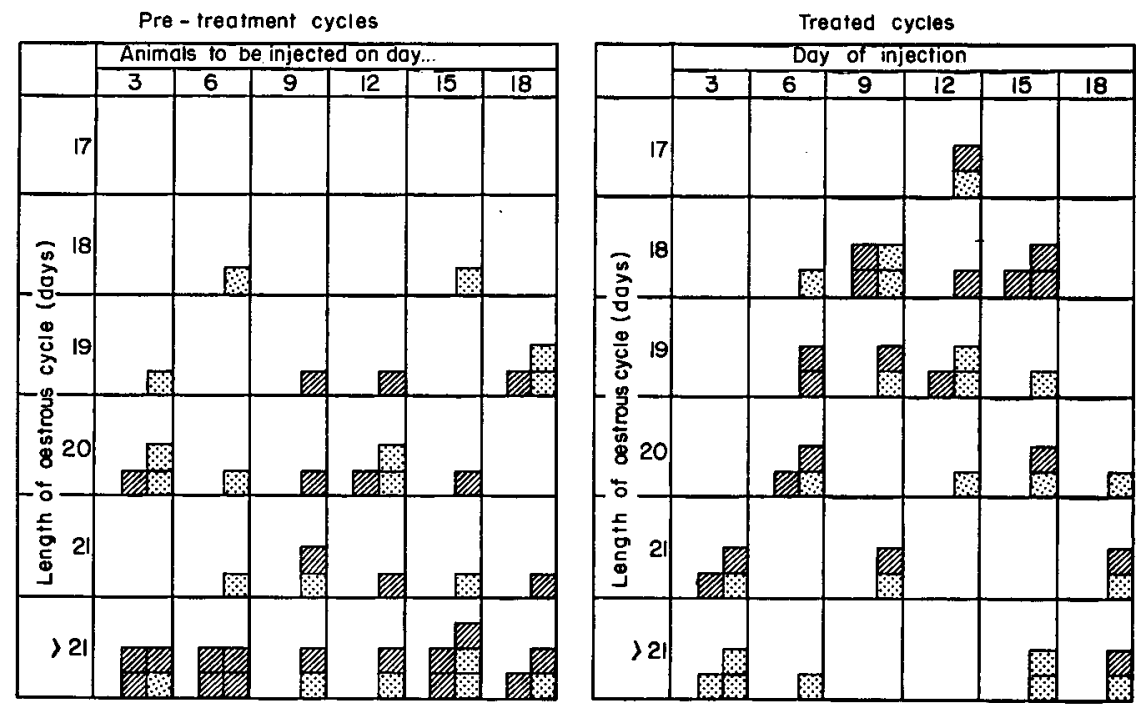

WIISA Destradiol Denzoote injection

80 Cestradiol volerate injection

Fig. 3. - The effect of oestrogen injection on the length of oestrous cycles in cyclic cor's

Each square represents one cow in oestrus after injection of oestradiol benzoate, or one cow in oestrus after injection of oestradiol valerate 
from this figure that luteal regression took place earlier, after oestradiol benzoate injection on Days 9 , I2 or $I_{5}$ than after injection on Days 3 or 6 . Similar results were observed after administration of oestradiol valerate, but early luteal regression was then produced in the groups injected on Days 6 and 9. Throughout this experiment, it became evident that there is a delay in the action of oestradiol valerate compared with oestradiol benzoate. The effects of each oestrogen are similar, but with a time lag of three days between the two.

As a result of the effect of oestrogen injection on the life-span of the corpus luteum, the length of the oestrous cycle is also altered, as shown in figure 3. By taking the lengths of the pre-injection cycles and comparing them with the following cycles where oestrogen was administered, each animal served as its own control. Before injection, the distribution of the cycle lengths was fairly random, with a large proportion of cycles longer than 2 I days ( $46.5 \mathrm{p}$. IOO). The cycle lengths decreased after injection of either oestrogen in midcycle, but there was no effect when injected either early or late in the cycle. It can be seen from this figure that the oestrous

TABLE 2

Effect of oestrogen injection on subsequent ovulation and fertility

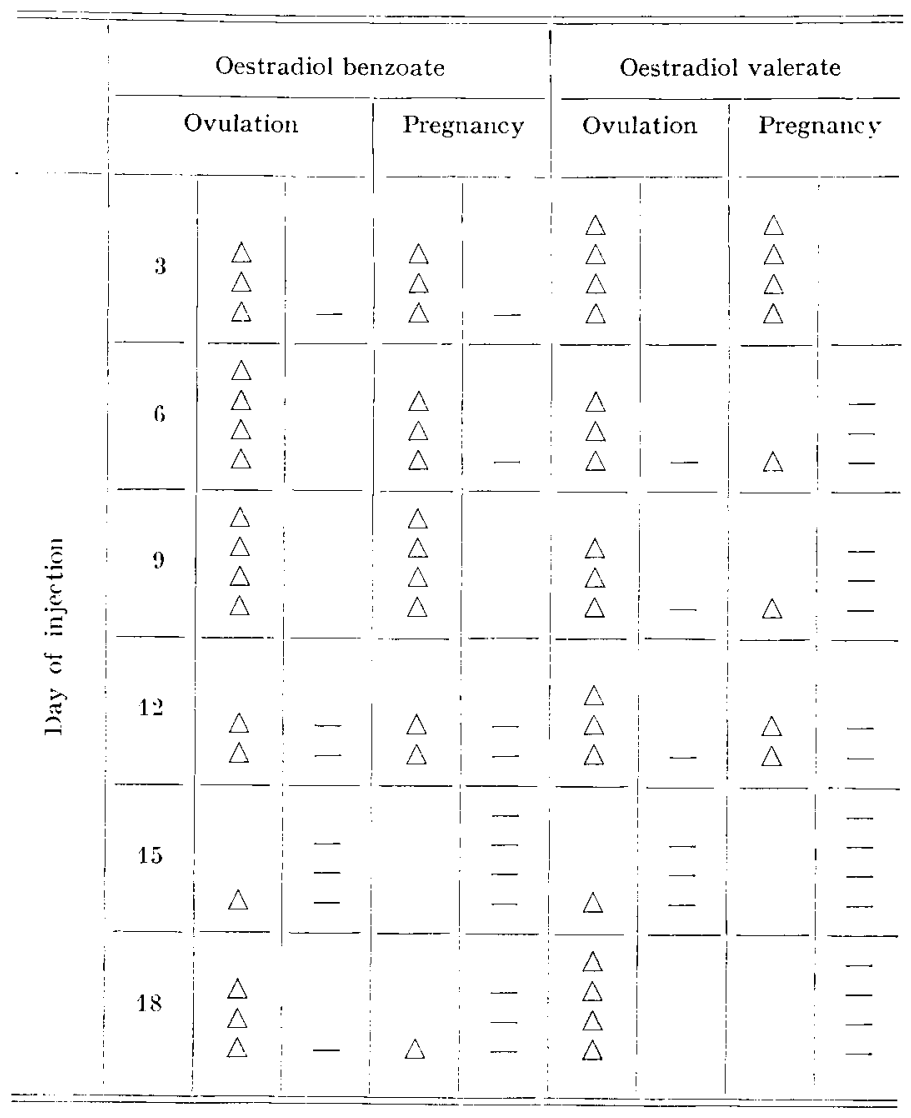


cycle lengths of cows injected on Days 3 and I 8 were not altered compared to the control cycles, but after injection on any of Days 6 to 15 , there was a large proportion (46.3 p. IOo) of cycles from I7 to I9 days' duration.

The assay of progesterone concentrations in the plasma samples taken on Days 8 and 23 after oestrus and artificial insemination allowed an estimation of whether or not ovulation had occurred (concentrations $>1.5 \mathrm{ng} / \mathrm{ml}$ on Day 8 ) and of whether or not the animals were pregnant (concentrations $>2 \mathrm{ng} / \mathrm{ml}$ on Day 23). These results are shown in table 2 . An effect on ovulation was not evident, but that there was a marked effect on fertilization, the later in the cycle that the oestrogen was injected, is suggested by the fact that there were few cows pregnant following oestradiol benzoate injection later than Day I2, and oestradiol valerate injection later than Day 6. It has been suggested that deleterious effects on fertilization could be due to an effect of oestrogen on tubal transport of ova (HUMPHREY, I968), or on sperm survival and transport (Robinson, I973). Early work with oestrogens in cattle showed that cows injected with oestrogen at the end of the cycle tended to have cystic ovaries (WILTBANK et al., I96I) ; although this was not examined in the present experiment, many of the animals injected on Day 18 , although showing regular oestrous behaviour subsequently, did not conceive after oestrogen injection, for several cycles at least.

\section{THE EFFECT OF PROGESTAGEN TREATMENT}

\section{IN THE CYCIIC COW}

Field trials have shown a differential effect between the two progestagens, norethandrolone and SC $2 \mathrm{IOOg}$, in association with an injection of oestradiol valerate when treatment is begun early in the oestrous cycle (P. MAULÉoN, personal communication). Keeping in mind the results obtained in the experiment described above, and the fact that the oestrogens proved not to be luteolytic in all cows when injected early in the cycle, the following experiment was designed to study the effects of progestagen treatments alone, or in association with oestradiol valerate injection.

In this experiment, there were 36 cyclic Friesian heifers, divided into 9 treatment groups of 4 animals per group. Treatments were with norethandrolone, $7 \mathrm{mg} / \mathrm{day}$ injected intra-muscularly for Io days, with and without an injection of $5 \mathrm{mg}$ oestradiol valerate on the first day.

This was compared with the administration of SC 2 IOog in the form of a subcutaneous implant containing I2 $\mathrm{mg}$ of the progestagen, left in place for Io days, again, with and without an injection of $5 \mathrm{mg}$ oestradiol valerate on the first day. A final group was included which received an implant containing $6 \mathrm{mg} \mathrm{SC} 2$ Ioog combined with injections of $5 \mathrm{mg}$ oestradiol valerate and $3 \mathrm{mg}$ SC 21009 on the first day. All treatments were begun on Days 3 or 5 of the cycle. Blood sampling was begun on Day I of the cycle, and continued once daily until oestrus, with one sample taken on Day 8 after oestrus to check for ovulation. The animals were not inseminated at oestrus, so no check could be made on fertility.

When progesterone concentrations were estimated in the daily plasma samples, the results in each treatment group were as shown in figure 4 . It is evident that 


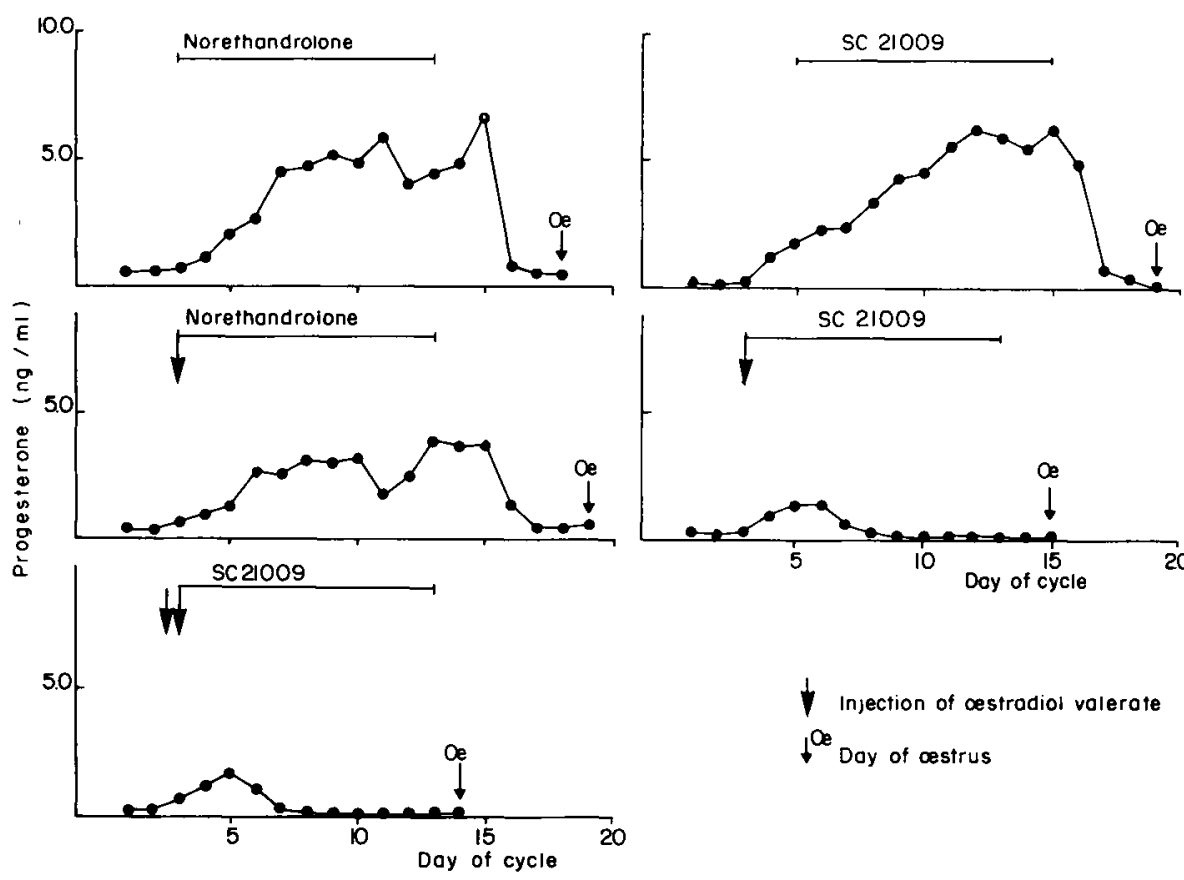

Fig. 4. - Effect of progestagen treatment (with and without oestradiol valerate) on progesterone concentrations in the cyclic heifer

after a ro day treatment with either of the progestagens used in this experiment, there was no effect on the development and life-span of the corpus luteum. Progesterone concentrations increased to normal levels during the luteal phase, luteal regression also occurred as in a normal cycle, and cycle lengths were not altered. When combined with an injection of oestradiol valerate at the beginning of treatment, the effects were different : with norethandrolone, some inhibition of corpus luteum development occurred, compared with the normal cycle, although there was no effect on the life-span of the corpus luteum and the resulting cycle length. With $\mathrm{SC} 2 \mathrm{roog}$ however, the inhibitory, or anti-luteotrophic effect was much more pronounced, and cycle lengths were decreased markedly with either of the two regimes used. The effects of the different treatments on the life-span of the corpus luteum, and the moment of luteal regression is shown in figure $5:$ as in figure 2, cumulative results are shown for each treatment regime, showing the number of cows in each group with progesterone concentrations below $2 \mathrm{ng} / \mathrm{ml}$, and in oestrus on different days of the cycle. Again, the marked effect of the combination of SC 21009 with oestradiol valerate is seen, in contrast to the other regimes. There seems to be a difference in the response when this treatment is begun on Day 3, and when it is begun on Day 5 : it appears that the earlier in the cycle the treatment is begun, the greater is the inhibitory, or anti-luteotrophic effect.

Figure 6 shows the effect of the different treatments on the lengths of the oestrous cycles. It can be seen that any of the three treatments, norethandrolone, norethandrolone plus oestradiol valerate, or SC 2Ioog, when started on Day 3 or 5 of the oestrous cycle, had no effect on the length of the oestrous cycle. This is in 


\begin{tabular}{|c|c|c|c|c|c|c|c|c|c|c|c|}
\hline \multirow{2}{*}{ Treotment } & \multirow{2}{*}{ Day } & \multicolumn{10}{|c|}{ Day of cycle } \\
\hline & & 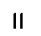 & 12 & 13 & 14 & 15 & 16 & 17 & 18 & 19 & 20 \\
\hline Norethandrolone & 3 & & & & & & $\frac{1}{2}$ & $\begin{array}{ll} \\
2 \\
\end{array}$ & $\frac{1}{\frac{1}{3}}$ & 3 & \begin{tabular}{|l}
3 \\
\end{tabular} \\
\hline $\begin{array}{l}\text { Norethandrolone } \\
\text { Volerate }\end{array}$ & 3 & & & & & & $\frac{1}{2}$ & \begin{tabular}{|l|}
$\frac{1}{2}$ \\
\end{tabular} & \begin{tabular}{|l|}
$\frac{1}{2}$ \\
3 \\
\end{tabular} & $\frac{1}{2}$ & $\frac{3}{4}$ \\
\hline Norethandrolone & 5 & & & & & & & 1 & \begin{tabular}{|l|}
1 \\
2 \\
\end{tabular} & \begin{tabular}{|l|}
$\frac{1}{2}$ \\
3 \\
\end{tabular} & \begin{tabular}{|l|}
2 \\
3 \\
4 \\
\end{tabular} \\
\hline $\begin{array}{l}\text { Norethondrolone } \\
\text { Valerate }\end{array}$ & 5 & & & & & $\frac{1}{2}$ & \begin{tabular}{|l|}
$\frac{1}{2}$ \\
$\frac{3}{4}$ \\
\end{tabular} & \begin{tabular}{|c|}
$\frac{1}{2}$ \\
$\frac{2}{3}$ \\
4 \\
\end{tabular} & \begin{tabular}{|l|}
$\frac{11}{2}$ \\
$\frac{3}{4}$ \\
\end{tabular} & $\frac{2}{3}$ & \\
\hline SC 21009 & 3 & & & & & & 1 & \begin{tabular}{|l|}
1 \\
2 \\
3 \\
\end{tabular} & \begin{tabular}{|l|}
$\frac{1}{3}$ \\
\end{tabular} & 2 & $\frac{3}{4}$ \\
\hline $\begin{array}{l}\text { SC } 21009 \\
\text { Valerate }\end{array}$ & 3 & $\frac{1}{2}$ & $\frac{1}{2}$ & $\frac{1}{2}$ & \begin{tabular}{|l|}
$\frac{T}{2}$ \\
3 \\
\end{tabular} & \begin{tabular}{|l|}
2 \\
3 \\
\end{tabular} & \begin{tabular}{|l|}
2 \\
\end{tabular} & $\frac{1}{3}$ & 3 & sers & \\
\hline SC 21009 & 5 & & & & & & & $\pi$ & $\frac{1}{2}$ & \begin{tabular}{|l|} 
\\
2 \\
3 \\
\end{tabular} & \begin{tabular}{|l|}
$\frac{2}{3}$ \\
4 \\
\end{tabular} \\
\hline $\begin{array}{l}S C 21009 \\
\text { Volerate }\end{array}$ & 5 & & & & & \begin{tabular}{|l|}
1 \\
2 \\
3 \\
\end{tabular} & \begin{tabular}{|l|}
1 \\
3 \\
\end{tabular} & \begin{tabular}{|l|}
$\frac{2}{3}$ \\
\end{tabular} & 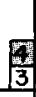 & 国 & \\
\hline $\begin{array}{l}\text { SC } 21009 \\
\text { Volerate } \\
\text { SC } 21009\end{array}$ & 3 & \begin{tabular}{|l|}
$\frac{1}{2}$ \\
$\frac{2}{3}$ \\
\end{tabular} & $\frac{1}{\frac{1}{2}}$ & \begin{tabular}{|l|}
$\frac{1}{2}$ \\
3 \\
3 \\
\end{tabular} & $\frac{1}{3}$ & 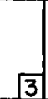 & 3 & 3 & 73 & & \\
\hline
\end{tabular}

Progesterone concentration $<2 \mathrm{ng} / \mathrm{ml}$

20strus

FIG. 5. - Influence of progestagen treatment on subsequent luteal regression in cyclic heifer:

\begin{tabular}{|c|c|c|c|c|c|c|c|c|c|c|}
\hline \multirow{2}{*}{ Treatment } & \multirow{2}{*}{ Doy } & \multicolumn{9}{|c|}{ Length of astrous cycle (days) } \\
\hline & & 14 & 15 & 16 & 17 & 18 & 19 & 20 & 21 & $>21$ \\
\hline Norethandrolone & $\begin{array}{l}3 \\
5\end{array}$ & & & & & & & & & \\
\hline $\begin{array}{l}\text { Norethondrolone } \\
\text { Valerote }\end{array}$ & $\begin{array}{l}3 \\
5\end{array}$ & & & & & & & & & \\
\hline SC 21009 & $\begin{array}{l}3 \\
5\end{array}$ & & & & & & & & & \\
\hline $\begin{array}{l}\text { SC } 21009 \\
\text { Volerate }\end{array}$ & $\begin{array}{l}3 \\
5\end{array}$ & & & & & 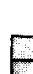 & & & & \\
\hline $\begin{array}{l}\text { SC } 21009 \\
\text { volerote } \\
\text { SC } 21009\end{array}$ & 3 & & & & & & & & & \\
\hline
\end{tabular}

0 Represents one heifer in cestrus

Fra. 6. - Effect of progestagen treatment on length of oestrous cycle in cyclic heifors 
contrast to the association of SC 21009 with oestradiol valerate, in either of the two regimes used. Although oestradiol valerate as a single injection had no effect on corpus luteum development at this stage, and neither had the $\mathrm{SC} 2 \mathrm{roog}$ when administered alone, a combination of the two compounds reduced the length of the oestrous cycle by 4 to 7 days. Unlike the difference which appeared between the day this treatment began and the regression of the corpus luteum, there was no difference in the cycle lengths between treatments begun on Day 3 and Day 5 .

As far as effects of all these treatments on ovulation are concerned, there was very little effect on the incidence of ovulation $\left(3 \mathrm{I} / 3^{6}\right)$ and no difference among treatments.

\section{CONCI,USIONS}

The first of the experiments described above has shown that the luteolytic effect of the oestrogens, oestradiol benzoate and oestradiol valerate is evident only when they are administered during the luteal phase of the oestrous cycle where in addition, further corpus luteum development is inhibited if the corpus luteum has not attained its maximum activity. In the case of oestradiol valerate, there is a delay of three days in its action, compared to oestradiol benzoate. At the beginning of the oestrous cycle, the effects may be either luteotrophic, with corpus luteum development in excess of normal, or anti-luteotrophic, in which case there is little or no luteal growth. In the latter case, it appears that there is a critical period of short duration, where the effect of the oestrogens may be reversed. At the end of the cycle, an anti-luteolytic, or luteotrophic action is again seen. These oestrogens seem to have little effect on the incidence of ovulation, but interfere in some way with fertilization when administered during the second half of the cycle.

The combination of progestagen treatment with an injection of oestradiol valerate modifies the action of the oestrogen when administered early in the oestrous cycle, especially with the progestagen SC 2 roog.

Colloque: Control of sexual cycles in domestic animals October $27-30,1974$, Nouzilly.

\section{ACKNOWLEDGEMENTS}

The author wishes to thank Dr. P. Mauleon of the Station de Physiologic de la Reproduction for his help with the planning of these experiments and for discussion and criticism of the results.

\section{RÉSUMÉ}

EFFET DES ESTROGENES SEULS OU EN ASSOCIATION

AVEC DES PROGESTOGËES SUR LA FORMATION

ET IA RÉGRESSION DU CORPS JAUNE CHEZ LA VACHE CYCLIQUE

Les œstrogènes ont des effets différents sur le corps jaune des mammifères, selon le stade du cycle ostrien où ils sont administrés. Nous rapportons ici une étude de l'effet d'une injection soit de $5 \mathrm{mg}$ de benzoate d'oestradiol, soit de $5 \mathrm{mg}$ de valerate d'œestradiol, sur le corps jaune à tous les stades du cycle chez la vache. 
Nous avons utilisé comme critères pour évaluer les effets sur le corps jaune, la concentration journalière de progestérone dans le plasma du sang périphérique, l'apparition d'cestrus, l'existence d'ovulation ct l'obtention d'une gestation.

Les résultats ont montré une multiplicité d'effets : effet lutéotrope ou anti-lutéotropc au lébut du cycle, effet luteolytique pendant la plus grande partie de la phase lutéale, et effet antiluteolytique à la fin du cycle.

Nous avons utilisé les mêmes critères pour évaluer l'effet de l'association d'un traitement de Io jours d'un progestagène de synthèse (norethandrolone ou $\mathrm{SC} 2$ toog) avec une scule injection de valerate d'œestradiol au début du traitement - les traitements utilisés couramment pour la synchronisation d'œestrus chez la vache. Tous les traitements ont été débutés, tôt dans le cycle restrien (les jours 3 ou 5) ; nous avons déjà montré dans l'expérience précédente qu'une injection seule de cet exstrogène n'a pas d'effet sur le corps jaune de cet âge. Il apparaît que le SC: 2 Ioog, en association avec le valerate d'ostradiol inhibe davantage le développement du corps jaune que ne fait l'association de la norethandrolone avec le valerate d'mestradiol.

\section{REFEREXCES}

Chepre D., Melemaxg F., Pete M., Pelot J., Le Provost F., Ortaraxt R., Parez M., MalLeox P., 1974. Utilisation de progestagènes en implants sous-cutanés pour la maitrise des cycles sexuels chez les bovins. Ann. Biol. anim. Bioch. Biophys., 14, 27-39.

HumpHRE li. W., 1968. The effects of oestradiol-3, - I7 on tubal transport in the laboratory mouse. J. Endocr., 42, I $7-26$.

Malleon P., 1974. Now trends in the control of reproduction in the bovine. Livestock production Science, 1, I 17 -I 3 I.

Roвrsox T. J., I973. Factors involved in the failure of sperm transport and survival in the female reproductive tract. J. Reprod. Fert., Suppl. i8, I03-109.

Tinmonier J., 1973. Diagriostic précoce de la gestation par l'estimation du taux de progestérone plasmatique chez la Brebis, la Vache et la Jument. Rec. Méd. I'et., Alfort, 149, I303-1318.

Thorbtre G. D., Bassett J. M., Smiti I. D, ig69. Progesterone concentration in the peripheral plasma of sheep during the oestrous cycle. J. Endocy., 45, 459-469.

WiltBaxi J. N., I966. Modification of ovarian activity in the bovine following injection of oestrogen and gonadotrophin. J. Reprod. Fert., Suppl. I, I-8.

Wiltbaxis J. N., INGalls J. J., RowDex W. W., I96I. liffects of various forms and levels of oestrogens alone or in combination with gonadotrophins on the oestrous cycle of beef heifers. J. Anim Sci, $20,34 I-346$.

WiltBaNis J. N., Kasson C. W., r968. Synchronisation of estrus ju cattle with an oral progestational agent and an injection of an estrogen. J. Anim. Sci., 27, I I3-II $\%$. 